\title{
Analysis on the Utilization Efficiency and Influencing Factors of Local Government Debt Based on DEA Model
}

\author{
Chang Liu* \\ School of Economics and Management, Beijing University of Posts and Telecommunications, \\ Beijing 100876, China \\ ciqi_china9610@163.com
}

\begin{abstract}
Local government debt reform is an important part of supply-side structural reform. Accelerating the deleveraging of local government debt, and improving the utilization efficiency of local government debt can provide a good financial environment for the implementation of supply side structural reform. Based on the DEA method, this paper has measured the utilization efficiency of local government debt investment output level, and analyzed the mechanism of local government debt scale and utilization efficiency from the perspective of economic cycle fluctuation, supply and demand, speculative demand, performance-driven mechanism and financial system. Finally, the paper puts forward some pertinent suggestions.
\end{abstract}

Keywords: local debt; utilization efficiency; influencing factors

\section{Introduction}

Local government debt reform plays an important role in supply-side structural reform. Accelerating the deleveraging of local government debt and improving the utilization efficiency of local government debt can optimize local government balance sheet, resolve debt risk effectively, and provide a good public financial environment for the implementation of the supply-side structural reform. Before the New Budget Law was introduced, local government built infrastructure with debt from financing platform, which played a positive role in economic development. During the 13th Five-Year Plan, China is in the economic growth shift period and structural adjustment pain period, and the economy is facing greater downward pressure. Besides, the conflict between local strong demand for financing and the huge scale of local debt is increasingly growing. Therefore, accelerating local government debt reform and improving the utilization efficiency of local government debt are of great significance to the stability of economic growth. According to the data from the Ministry of Finance, local governments had debts of up to 16 trillion and contingent liabilities more than 7 trillion at the end of 2015. Such a great scale of local government debt affects the government financial security and even threatens the stability and sustainability of social and economic development.

From the perspective of scholars and economists in China, the main reasons for the expansion of local government debt are in three aspects: urbanization and land finance, fiscal decentralization and taxation, and budget soft constraints.

He Yang (2014) , Duan Zhenwen (2013), and Chen Zhiyong (2014) hold that the local government debt growth is mainly attributed to "land credit" kidnapping "government credit". That local investment and financing system is not perfect led that the role of land fiscal leverage is too large. And the process of urbanization is promoted through the accumulation of local government debt.

Zhu Jun (2014) and Wang Yaling (2015) conclude that the budget constraint has some relations with government debt. The results show that the relaxation and softening of the budget constraint condone the behavior of the local government to engage in debt, and the lack of effective supervision of the local government financing platform resulted in a very high debt repayment ratio. 
With the development of local debt and incremental amount, scholars have studied from the perspective of risk management, and have measured local government debt efficiency through quantitative models.

Ba Shusong (2014), Lin Yifu (2014) and Liu Shangxi (2015) believe that effective correction of local government large-scale debt behavior should derive from the aspects of fiscal constraints, market constraints, and public constraints. And at the same time, the risk identification and supervision feedback mechanism should be established and improved so that the local government debt should be under risk identification prior to the event, under risk monitoring in the event, and under risk assessment and feedback after the event. When the scale of local government debt is maintained at a certain level, the efficiency of the government's investment has a significant impact on the late debt scale.

Many scholars use the Balanced Scorecard, fuzzy comprehensive evaluation, analytic hierarchy process, DEA model and other evaluation methods to evaluate the efficiency of local government debt.

Gao Xuewu (2014), Hong Yuan (2014), Fan Zheng (2014) and others use the DEA method to measure the utilization of local government debt. They come to the conclusion that the utilization efficiency of China's local government debt is relatively low.

Miu Xiaolin, Cheng Lina (2015), Zhang Tonggong (2015), Wang Xuekai(2016) , Xu Zhandong, Wang Xuebiao (2016) and others point out the factors that affect the risk of government debt, and they provide sustainable optimization recommendations for local government debt.

\section{Method and Data}

Considering the investment of local government debt funds, about 80 percent of the funds was invested into infrastructure, science and education, cultural and environmental protection, and some other public areas. Therefore, the investment of local government debt belongs to the "single-input, multi-output" model. Meanwhile, the effect of input-output is influenced by external factors such as regional economic policy, industrial structure and market environment. Therefore, this paper apply DEA model and eliminate the interference of environmental factors, which to a certain extent can optimize the redundant variables of local government debt investment. And then the paper can make a more accurate and authentic measure of the utilization efficiency of local government debt.

\subsection{DEA Measure Method}

This paper selects the factors that affect the input and output of the evaluation subject, and the environmental variable factors. Also, this paper uses the original input and output variables to measure technical efficiency, pure technical efficiency and scale efficiency. Based on the characteristics of this paper, the input-oriented BCC model is employed to measure the utilization efficiency of local government debt input. The model equations are

$$
\text { s.t. }\left\{\begin{array}{l}
\min \theta-\varepsilon\left(\hat{e}^{T} S^{-}+e^{T} S^{+}\right) \\
\sum_{i=1}^{n} X_{i} \lambda_{i}+S^{-}=\theta X_{0} \\
\sum_{i=1}^{n} Y_{i} \lambda_{i}-S^{+}=Y_{0} \\
\lambda_{i} \geq 0, S^{-}, S^{+} \geq 0
\end{array}\right.
$$

In the model, the input vector is $\mathrm{X}$, the output vector is $\mathrm{Y}, \mathrm{S}$ is the slack variable, S+ represents the output slack variable, $S$ - represents the input slack variable, and i represents the decision unit.

\subsection{Data Source and Variable Selection}

1. Input Variable. Considering the validity and availability of the data, this paper chooses the per capita debt scale $(\mathrm{X})$ as the input indicator.

2. Output Variable. According to the audit results of the Audit Commission, most of China's local funds are invested in infrastructure construction, agriculture, forestry, water conservancy construction and public services. It is estimated that by the end of June 2013, the investment in these 
three areas accounted for $74.81 \%$, and the proportion of municipal construction, transportation construction, science and education, agriculture, forestry and water conservancy was 34.64\%, $24.43 \%, 12.34 \%$ and $3.4 \%$ respectively. Therefore, according to the capital flow and the principle of input and output, this paper chooses the per capita highway mileage (Y1), per capita farmland irrigation area (Y2), and the number of people with a college or higher education degree (Y3) as output indicator. All the indicators are shown in Table 1.

3. Environmental Variable. China's local debt scale is not just restrained by the local economic constraints. Society, policy and market environment will also affect the debt scale, the subjects of debt and debt management. Therefore, this paper chooses per capita GDP (S1) as an economic environment variable, per capita education investment (S2) as a social environment variable, government budget investment / fiscal expenditure (S3) as a policy environment variable, and the tertiary industry output / GDP (S4) as a variable of measuring the degree of marketization.

4. Data Resource. The data come from the year of 2010 to 2015. The value comes from the China Statistical Yearbook, China Financial Statistical Yearbook, WIND database, provincial statistical bulletins and eastmoney.com.

Table 1 Input Variable, Output Variable, and Environmental Variable

\begin{tabular}{|c|c|c|l|}
\hline \multirow{4}{*}{ Input Indicator } & Variable & Symbol & \multicolumn{1}{|c|}{ Variable Explanation } \\
\hline \multirow{4}{*}{$\begin{array}{c}\text { Output } \\
\text { Indicator }\end{array}$} & per capita debt scale & $\mathrm{X}$ & $\begin{array}{l}\text { Reflecting the input of local government } \\
\text { debt }\end{array}$ \\
\cline { 2 - 4 } & $\begin{array}{c}\text { per capita farmland } \\
\text { irrigation area }\end{array}$ & Y2 & $\begin{array}{l}\text { Representing the output indicators of } \\
\text { agriculture, forestry, and water } \\
\text { conservancy construction }\end{array}$ \\
\cline { 2 - 5 } & $\begin{array}{c}\text { the number of people with } \\
\text { a college or higher } \\
\text { education degree }\end{array}$ & Y3 & $\begin{array}{l}\text { Reflecting the output indicators of } \\
\text { governmental science, education, health, } \\
\text { and areas of livelihood }\end{array}$ \\
\hline \multirow{4}{*}{$\begin{array}{c}\text { Environmental capita GDP } \\
\text { Variable }\end{array}$} & $\begin{array}{c}\text { per capita education } \\
\text { investment }\end{array}$ & S2 & As an economic environment variable \\
\cline { 2 - 4 } & $\begin{array}{c}\text { government budget } \\
\text { investment / fiscal } \\
\text { expenditure }\end{array}$ & S3 & As a policy environment variable \\
\cline { 2 - 4 } & $\begin{array}{c}\text { tertiary industry output / } \\
\text { GDP }\end{array}$ & S4 & $\begin{array}{l}\text { As a variable of measuring the degree of } \\
\text { marketization }\end{array}$ \\
\hline
\end{tabular}

\section{Results}

Based on the DEA-Malmquist model and got rid of the impact of environmental variables, the utilization efficiency of the input and output of 31 provincial and municipal local government debt in China during 2010 to 2015 is measured, and the results are shown in Table 2. 
Table 2 The Utilization Efficiency of 31 Provincial and Municipal Local Government Debt in China during 2010 to 2015

\begin{tabular}{|l|c|c|r|l|l|r|r|}
\hline $\begin{array}{c}\text { Local } \\
\text { Government }\end{array}$ & TE & PTE & SE & $\begin{array}{c}\text { Local } \\
\text { Government }\end{array}$ & TE & PTE & \multicolumn{1}{c|}{ SE } \\
\hline Beijing & 0.795 & 0.755 & 1.042 & Hubei & 0.798 & 0.776 & 1.017 \\
\hline Tianjin & 0.831 & 0.747 & 1.101 & Hunan & 0.860 & 0.776 & 1.098 \\
\hline Hebei & 0.838 & 0.791 & 1.049 & Guangdong & 0.769 & 0.769 & 0.990 \\
\hline Shanxi & 0.788 & 0.752 & 1.038 & Guangxi & 0.812 & 0.753 & 1.066 \\
\hline Inner Mongolia & 0.820 & 1.020 & 0.795 & Hainan & 0.810 & 0.739 & 1.087 \\
\hline Liaoning & 0.789 & 0.763 & 1.025 & Chongqing & 0.798 & 0.736 & 1.074 \\
\hline Jilin & 0.765 & 0.749 & 1.011 & Sichuan & 0.827 & 0.770 & 1.062 \\
\hline Heilongjiang & 0.763 & 0.763 & 0.990 & Guizhou & 0.846 & 0.759 & 1.103 \\
\hline Shanghai & 0.741 & 0.749 & 0.979 & Yunnan & 0.715 & 0.746 & 0.948 \\
\hline Jiangsu & 0.867 & 0.784 & 1.095 & Xizang & 0.812 & 0.755 & 1.063 \\
\hline Zhejiang & 0.880 & 0.762 & 1.143 & Shaanxi & 0.719 & 0.736 & 0.967 \\
\hline Anhui & 0.789 & 0.785 & 0.994 & Gansu & 0.753 & 0.743 & 1.003 \\
\hline Fujian & 0.850 & 0.744 & 1.131 & Qinghai & 0.729 & 0.741 & 0.973 \\
\hline Shanxi & 0.776 & 0.743 & 1.034 & Ningxia & 0.803 & 0.736 & 1.080 \\
\hline Shandong & 0.885 & 0.885 & 0.990 & Xinjiang & 0.726 & 0.781 & 0.920 \\
\hline Henan & 0.806 & 0.806 & 0.990 & Average & $\mathbf{0 . 7 9 9}$ & $\mathbf{0 . 7 7 2}$ & $\mathbf{1 . 0 2 8}$ \\
\hline
\end{tabular}

According to the China Statistical Yearbook (2010-2015), China Financial Statistical Yearbook, WIND database, provincial statistical bulletins, eastmoney.com, and other related data

The results show that during 2010 to 2015 , the average of technological efficiency is 0.799 , the average of pure technical efficiency is 0.772 , the average of scale efficiency is 1.028 , and the scale efficiency is strictly better than technical efficiency. The difference of the technical efficiency of China's 31 provinces and cities is quite large: the average of technical efficiency of Shandong Province reached 0.885, which ranks first in the country; the use efficiencies of Beijing, Tianjin, Anhui, and Hunan provincial government debts are relatively higher, while the efficiencies of Yunnan, Shanxi, Qinghai, and Xinjiang provincial government debts are relatively lower.

However, it is noteworthy that the utilization efficiency of government debt of Shanghai is not very high. The probable reason is that Shanghai's urbanization development level is relatively higher, and the investment growth rate of the regional infrastructure and other debt output index has slowed, which further affects the utilization efficiency. But most provinces and cities in China still have investment-driven economy, in which government debt investments play a significant role. Thus, the overall results of the measurement are scientific.

\section{Discussions}

Through the DEA model, it is measured that the economic environment, social environment, policy environment and market environment have important influence on the utilization efficiency of local government debt. Yet it needs specific discussion about how these environmental variables impose impact on local government debt mechanism. Local government debt follows the process of "borrowing - utilization - reimbursement - borrowing", and the path of this cycle is the "assessment index - fixed asset investment - debt expansion" transmission mechanism. Therefore, the scale of debt and the utilization efficiency of local government funds are closely related. Li Xinguang (2016) and others had deep study in the influential factors of the scale of local government, and they raise proposals from economic, financial, management and other aspects, respectively. This paper holds that there are five main factors that affect the scale and utilization efficiency of local government debt, which are economic development and economic cycle fluctuations factors, supply and demand aspects factor, political achievement-oriented driving mechanism factor, and China's fiscal system factor, respectively. 


\subsection{Economic Development and Economic Cycle Fluctuations Factors}

Economic fluctuation theory holds that economic fluctuation and economic cycle are objective laws of economic development process. The economic cycle promotes the accumulation of wealth, but also produces the accumulation of government debt. And the economic cycle and debt scale show the changes of same proportion. When the economy is in its high growth period, the fixed investment rate is the fastest, and the local government's investment scale for the regional infrastructure and social public service is the largest. Even if the economy is being adjusted, just as today's economic restructuring period and growth shift period, the government still need a lot of investment, and expand expenditure on social transfers and on government public purchases, so as to revitalize the stock and to expand the increment.

\subsection{Supply and Demand Aspects Factor}

From the perspective of supply side, the government, which is the subject of debt, has a relatively weak ability to arrange funds, although it has the power of taxation and legislation. In addition, China's market decouples due to the imbalance between routine powers and financial powers which is the financial powers precede the routine powers specifically. The financial power is held by high-level government agencies, while the implementation of specific affairs is often attributed to the hierarchical local government. Thus, the arrangement of financial powers cannot keep up with the requirement of routine powers, which delays the utilization of government debt funds, and this lag will cause repeated debt.

From the perspective of demand side, local government financing platforms provide a good way for capital needs. However, with the acceleration of urbanization, the demand for public services has been improving continuously. Accordingly, a large amount of money is applied in the management system of road traffic and welfare security, and that increases the demand for debt.

\subsection{Political Achievement-Oriented Driving Mechanism Factor}

Local officials' eagerness to political achievements is a reason for the accumulation of more and more debt. At present, the indicator of GDP is still the core of China's local government assessment system. Accordingly, some local officials have the problem in governing ideas, and they abuse their power due to "political achievement first" and "GDP orientation". To stimulate economic growth, some local officials mobilize the financial, banking, and corporate funds wantonly. Investment orientation is repetitive and simplistic, and a large amount of money is invested in "face project" and "image project" in exchange for economic virtual prosperity at the expense of huge government debt. In addition, officials seek for large-scale financing through various means, and they use the funds to invest in fixed assets and infrastructure. Also, they absorb a huge amount of foreign investment to push up GDP output.

\subsection{China's Fiscal System Factor}

The problem of China's government debt risk, especially the local government debt risk, is rooted in China's fiscal system. Since the reform of tax distribution system, China's local fiscal revenue mainly comes from land revenue and real estate operating income. However, the imbalance of this fiscal and taxation system has seriously affected the income and expenditure of China's fiscal funds. Therefore, we must solve the problem from the root of the system to speed up the central and local financial system reform, and to improve the transparency of finance and debt.

\section{Conclusions}

Local government debt reform is an important part of supply-side structural reform. In order to improve the utilization efficiency of local government debt, China needs to clarify local government's routine powers and financial powers, standardize the development of local government financing platform, establish an efficient local government bond market, and establish local debt risk early warning mechanism. Then it can provide a good financial environment for the implementation of supply side structural reform. 


\section{References}

1.He Yang, Man Yanyun: Risk Control of Local Government Debt Financing - An Analysis Based on Land Finance. Finance \& Trade Economics, 2012(05):p45-50.

2.Duan Zhenwen: Study on the Risks of Local Government Financing Platform Loans and Its Influencing Factors.2014, Journal of China Agricultural University.p114.

3.Chen Zhiyong, Chen Sixia: Institutional environment, local government investment impulse and financial budget soft constraints. Economic Research Journal, 2014(03):p.76-87.

4.Zhu Jun, Nie Qun: Research on China 's Financial Sustainability under the Condition of Intertemporal Budget Constraints. Journal of Zhongnan University of Economics and Law, 2014(05): p.51-58+159.

5.Wang Yaling, Wang Lijie: Signal Game in the Formation of Local Debt: Real Estate Price - Also on the Influence of New Budget Law. Economic Perspectives, 2015(04):p59-68.

6.Ba Shusong: To Resolve the Debt Risk Needs "Combined Boxing". Review of Economic Research, 2014(36):p12-13.

7.Lin Yifu: The Real Estate and Local Government Debt Risk Needs Utmost Attention. Guangdong Economy, 2014(09):p8.

8.Liu Shangx: The Rule of Law of Local Government Debt. China State Finance, 2015(01):p44-49.

9.Gao Xuewu, Zhang Dan: A Re-examination of the Efficiency of Local Government Expenditure- An Analysis Based on Provincial Panel Data. Comparative Economic \& Social Systems, 2013(06):p181-190.

10.Hong Yuan, Qin Yuqi, Yang Sijian : Evaluation of Local Government Debt Utilization Efficiency and Spatial Spillover Effects: A Study Based on Three-stage DEA Model and Spatial Metrology. China Soft Science, 2014(10):p182-194.

11.Fan Zheng: Analysis on Investment Efficiency of Local Government Financing Platform Based on DEA Model. Southwestern University of Finance and Economics, 2014:p68.

12.Miu Xiaolin, Cheng Lina: The Logic and Thinking of PPP to Prevent the Debt Risk of Local Government in China - From "Behavioral Sacrifice Efficiency to" Mechanism ". Public Finance Research, 2015(08):p68-75.

13.Zhang Tonggong, Research on the Evaluation and Prevention of Local Government Debt Risk in China under the New Normality. Macroeconomics, 2015(09):p134-143.

14.Wang Xuekai: A Study on the Sustainability of Chinese Government Debt - Based on E29 Financial Reaction Function. Studies of International Finance, 2016(08):p38-47.

15.Xu Zhandong, Wang Xuebiao: Ponzi Debt Policy, Land Finance and Provincial Government Debt Sustainability. Economic Science, 2016(01):p17-28.

16.Li Xinguang, Hu Ridon: An Empirical Study on the Influencing Factors of Local Government Debt and the Effect of Space Infection. Statistics and Decision, 2016(16):p153-156. 